\title{
The formation of the dolomite-analogue norsethite: Reaction pathway and cation ordering
}

\author{
Carlos Pimentel, Carlos M. Pina* \\ Departamento de Cristalografía y Mineralogía, Facultad de Ciencias Geológicas, Universidad Complutense de Madrid, clJosé Antonio Novais, \\ 2, E-28040 Madrid, Spain \\ Instituto de Geociencias IGEO (UCM - CSIC), Madrid, Spain
}

\begin{abstract}
Reaction pathways and cation ordering mechanisms involved in the formation of the mineral dolomite in nature still remain poorly understood. This is mainly due to the experimental problems posed by the synthesis of dolomite at ambient conditions, which preclude monitoring its formation in reasonable time scales. However, processes leading to the crystallization of fully-ordered dolomite-like structures can be studied by conducting experiments with mineral analogues, which are more readily precipitated. In this paper we present a study of the formation of the dolomite-analogue norsethite $\left[\mathrm{BaMg}\left(\mathrm{CO}_{3}\right)_{2}\right]$ from a slurry which was aged at room temperature during 14 days. We found that norsethite forms by two dissolution-crystallization reactions from an initial amorphous nano-sized precipitate. The first reaction produces a mineral assemblage composed by witherite $\left[\mathrm{BaCO}_{3}\right]$, northupite $\left[\mathrm{Na}_{3} \mathrm{Mg}\left(\mathrm{CO}_{3}\right)_{2} \mathrm{Cl}\right]$ and norsethite. The second dissolution-crystallization process leads to the almost complete depletion of witherite and northupite in favor of norsethite. While the composition of norsethite crystals rapidly reaches a $\mathrm{Ba} / \mathrm{Mg}=1$ ratio, $\mathrm{X}$-ray diffraction peaks indicate an increase in the crystallinity of those crystals during the first $48 \mathrm{~h}$ of reaction. Simultaneously, $\mathrm{Ba}-\mathrm{Mg}$ cation ordering increases, as shown by the evolution of intensity ratios of certain superstructure and structure reflections. Altogether, these results demonstrate that the formation of fully-ordered norsethite occurs by a sequence of solvent-mediated processes which involve a number of precursors. Our study also suggests that similar processes might lead to the formation of dolomite in natural environments.
\end{abstract}

\section{INTRODUCTION}

The low-temperature formation of dolomite $\left(\mathrm{CaMg}\left(\mathrm{CO}_{3}\right)_{2}\right)$ is doubtless one of the most intriguing and longstanding mineralogical problems. In brief, the so-called "dolomite problem" can be described as follows: dolomite is a very common carbonate mineral, which at present does not form under the conditions inferred from most geochemical data. Actually, the dolomite problem is not a single

\footnotetext{
* Corresponding author.

E-mail addresses: cpimentelguerra@geo.ucm.es (C. Pimentel), cmpina@geo.ucm.es (C.M. Pina).
}

problem but it is rather a puzzle, which poses a number of fundamental physicochemical questions (e.g., Liebermann, 1967; Lippmann, 1973; Vasconcelos et al., 1995; Deelman, 2011 and references therein). Can dolomite directly precipitate from aqueous solutions or is the formation of crystalline and/or amorphous precursors a necessary step? If precursors are involved, what are they and what are the reaction pathways that eventually result in the dolomite formation? Does the dolomite precipitation occur only when some physicochemical parameters (e.g., pH, salinity, temperature) change cyclically? What is the role played by the relative size, charge and hydration of the $\mathrm{Ca}^{2+}$ and $\mathrm{Mg}^{2+}$ ions in the construction of the dolomite structure? What are the mechanisms and kinetics of cation ordering 
during the crystallization of dolomite? Can dolomite form only with the assistance of microorganisms which catalyze adequate chemical reactions?

Although much research effort has been done in the last hundred years to answer the above questions, interesting but only partial insights have been provided to date (Warren, 2000; Deelman, 2011 and references therein; Roberts et al., 2013). Whereas most of the previous research has been addressed to synthesize dolomite crystals under conditions more or less close to those found in natural environments, studies aimed to determine the reaction pathways leading to the formation of ordered dolomite structure are still scarce. One of the main reasons for the lack of systematic data on the processes involved in the crystallization of dolomite structure is, precisely, the intrinsic difficulty in synthesizing this mineral under ambient conditions and in reasonable time scales. A possible strategy to reduce experimental problems is to investigate the formation of crystalline phases with dolomite-like structures, which form easier than dolomite at room temperature and atmospheric pressure. Among these phases, the mineral norsethite, $\mathrm{BaMg}\left(\mathrm{CO}_{3}\right)_{2}$, has been recognized as an exceptional dolomite-analogue to perform crystallization experiments relevant to the dolomite problem (Lippmann, 1967; Hood et al., 1974; Morrow and Ricketts, 1986; Böttcher, 2000).

Norsethite crystallizes in the space group $R 32$ with hexagonal unit cell parameters $a=0.5017 \mathrm{~nm}, c=1.677 \mathrm{~nm}$, and $Z=3$ (Lippmann, 1973). Norsethite structure is essentially identical to that of dolomite. Only the orientation of the carbonate groups is slightly different in both mineral structures due to the larger ionic radius of $\mathrm{Ba}^{2+}$ compared with those of $\mathrm{Ca}^{2+}$ and $\mathrm{Mg}^{2+}$. As a result, norsethite exhibits a higher symmetry than dolomite (which crystallizes in the space group $R \overline{3}$ with hexagonal cell parameters $a=0.48079 \mathrm{~nm}, c=1.601 \mathrm{~nm}$, and $Z=3$ ). Therefore, norsethite and dolomite cannot be considered strictly isotypes (or isostructural), but homotypes, as pointed out by Lippmann (1966). In spite of this, cation ordering is evidenced in norsethite diffractograms by the presence of "dolomite-type" superstructure reflections indexed h0.1 and $0 \mathrm{k} .1$ with 1 odd (e.g., 00.3, 10.1, 01.5). As in the case of dolomite, such superstructure reflections are due to the existence of alternating monolayers of cations perpendicular to the $\mathrm{c}$ axis (i.e., $\mathrm{Ca}^{2+}$ and $\mathrm{Mg}^{2+}$ monolayers in dolomite, and $\mathrm{Ba}^{2+}$ and $\mathrm{Mg}^{2+}$ monolayers in norsethite).

Lippmann (1967) reported the first experimental protocol to synthesize norsethite at room temperature. In his experiments, norsethite did not crystallize directly from aqueous solutions but it was formed after reaction of highly concentrated $\mathrm{MgCl}_{2}$ aqueous solutions with a suspension of witherite $\left(\mathrm{BaCO}_{3}\right)$. This result was confirmed by a series of more systematic experiments performed by Morrow and Ricketts (1986). Other experiments carried out by Hood et al. (1974), have also shown that the formation of norsethite does not occur by direct precipitation when $\mathrm{BaCl}_{2}$, $\mathrm{MgCl}_{2}$ and $\mathrm{Na}_{2} \mathrm{CO}_{3}$ solutions are mixed at room temperature. Instead, a gel is instantaneously formed, which transforms into norsethite (or into mixtures of witherite and norsethite depending on the $\mathrm{Ba} / \mathrm{Mg}$ ratio in the initial solutions) after $24 \mathrm{~h}$.
The experimental findings summarized above provide some interesting insights into the problem of the formation of mineral phases with dolomite-like cation ordering. Undoubtedly, the most relevant among them is that such a cation ordering cannot be achieved by direct crystallization from aqueous solutions but by relatively complex solvent-mediated aging. Despite the importance of this conclusion, the reactions involved in the aging process leading to the formation of a phase with dolomite-like structure has not been identified yet.

In this paper, we present an investigation of the sequence of processes that result in the crystallization of the ordered phase norsethite from an amorphous precursor. On the basis of the experimental protocol described by Hood et al. (1974), we conducted a series of experiments in which the sequential dissolution-crystallization reactions leading to the formation of norsethite were identified. Furthermore, a detailed analysis of X-ray diffraction data indicates that during the crystallization of norsethite both crystallinity and cation ordering increase. The findings reported in this paper provide new insights into the possible mechanisms of dolomite precipitation.

\section{EXPERIMENTAL PROCEDURE}

Precipitation experiments addressed to synthesize norsethite were conducted by mixing solution $\mathrm{A}(0.06 \mathrm{M}$ of $\mathrm{BaCl}_{2} ; 0.1 \mathrm{M}$ of $\left.\mathrm{MgCl}_{2}\right)$ and solution $\mathrm{B}\left(0.5 \mathrm{M}\right.$ of $\left.\mathrm{Na}_{2} \mathrm{CO}_{3}\right)$ at room temperature. These starting solutions were prepared using reagent-grade chemicals by Sigma-Aldrich. Precipitation was observed immediately after adding volumes of $25 \mathrm{ml}$ of solution B to volumes of $25 \mathrm{ml}$ of solution A previously placed in 30 beakers. Then, beakers were rapidly closed with a plastic cup and both precipitates and remaining solutions were kept vigorously stirred with a magnetic stirrer. Precipitates were completely removed from the beakers each hour during the first day of the aging process and then after 2, 3, 5, 8 and 14 days (i.e., after 48, $72,120,192$ and $336 \mathrm{~h}$ ). The $\mathrm{pH}$ evolution during the aging of the precipitates was recorded with a $\mathrm{pH}$-meter (USB DrDAQ Data Logger, Pico Technology) equipped with a recording system (PicoLog Recorder 5). The probe of the $\mathrm{pH}$-meter was placed in one of the beakers and disconnected after the removal of precipitate in the last beaker. Initial saturation state of the solutions with respect to different solid phases was calculated using the following expressions: $\quad \beta_{\mathrm{wt}}=\left(\left[\mathrm{Ba}^{2+}\right] \cdot\left[\mathrm{CO}_{3}^{2-}\right]\right) / K_{\mathrm{sp}, \mathrm{wt}}$ for witherite $\left(\mathrm{BaCO}_{3}\right), \beta_{\mathrm{hl}}=\left(\left[\mathrm{Na}^{+}\right] \cdot\left[\mathrm{Cl}^{-}\right]\right) / K_{\mathrm{sp}, \mathrm{hl}}$ for halite, $\beta_{\mathrm{nt}}=\left(\left[\mathrm{Na}^{2+}\right]^{3}\right.$. $\left.\left[\mathrm{Mg}^{2+}\right] \cdot\left[\mathrm{CO}_{3}^{2-}\right]^{2} \cdot\left[\mathrm{Cl}^{-}\right]\right) / K_{\text {sp,nt }}$ for northupite $\left(\mathrm{Na}_{3} \mathrm{Mg}\left(\mathrm{CO}_{3}\right)_{2} \mathrm{Cl}\right)$, and $\beta_{\mathrm{ns}}=\left(\left[\mathrm{Ba}^{2+}\right] \cdot\left[\mathrm{Mg}^{2+}\right] \cdot\left[\mathrm{CO}_{3}^{2-}\right]^{2}\right) / K_{\mathrm{sp}, \mathrm{ns}}$ for norsethite $\left(\mathrm{BaMg}\left(\mathrm{CO}_{3}\right)_{2}\right)$. In these formulas, ionic activities in square brackets were calculated using the Pitzer formalism available in the PHREEQC computer code for chemical speciation of aqueous solutions (Parkhurst and Appelo, 1999). The solubility products of witherite, $K_{\mathrm{sp}, \mathrm{wt}}=10^{-8.56}$ and halite, $K_{\mathrm{sp}, \mathrm{hl}}=10^{1.57}$ are included in the PHREEQC.DAT and PITZER.DAT databases, respectively. The solubility products of norsethite, $K_{\mathrm{sp}, \mathrm{ns}}=10^{-16.72}$ and northupite, $K_{\mathrm{sp}, \mathrm{ns}}=10^{-4.8}$ were taken from Königsberger et al. (1998) and Vančina et al. (1986), respectively. Precipitates were 
filtered using standard filter paper (Filtros Anoia. S.A.) and dried at room temperature for more than $48 \mathrm{~h}$. Then, diffractograms of all precipitates were collected with a Siemens D-500 diffractometer equipped with a $\mathrm{Cu}-\mathrm{K} \alpha$ $\mathrm{X}$-ray source. Diffractograms were subsequently analyzed with the codes Diffracplus.Eva (Bruker) and XPowder. A selected number of samples were also imaged by scanning electron microscopy (SEM, JEOL JSM 6400-40 kV) and chemically analyzed with a Link-analytical Energy Dispersive X-ray Analysis (EDX) system.

\section{RESULTS AND DISCUSSION}

When solution $\mathrm{A}\left(0.06 \mathrm{M}\right.$ of $\mathrm{BaCl}_{2} ; 0.1 \mathrm{M}$ of $\left.\mathrm{MgCl}_{2}\right)$ and solution $\mathrm{B}\left(0.5 \mathrm{M}\right.$ of $\left.\mathrm{Na}_{2} \mathrm{CO}_{3}\right)$ are mixed, instantaneous precipitation is observed, as previously reported by Hood et al. (1974) and Böttcher (2000). Calculations conducted with the speciation code PHREEQC (using the Pitzer formalism for highly concentrated aqueous solutions) show that, immediately after mixing, the resulting solution is highly supersaturated with respect to witherite $\left(\beta_{\mathrm{wt}}=1.56 \times 10^{4}\right)$ and norsethite $\left(\beta_{\mathrm{ns}}=7.75 \times 10^{4}\right)$, slightly supersaturated with respect to northupite $\left(\beta_{\mathrm{nt}}=1.58\right)$, and undersaturated for halite $\left(\beta_{\mathrm{hl}}=8.71 \times 10^{-4}\right)$. However, none of the phases with respect to which the solution is supersaturated directly precipitates. Instead, an amorphous gel-like precipitate is instantaneously formed and diffractograms only show very weak peaks of crystalline phases in the first hours of slurry aging. Since the solution is highly undersaturated with respect to halite, the occasional detection of this phase in the diffractograms is not considered relevant and it can be attributed to the drying process of precipitates that can contain remnants of solution after filtering. From EDX analyses, the following chemical composition for the amorphous phase was determined: $\mathrm{Na}(14.26 \%), \mathrm{Mg}(4.50 \%), \mathrm{Cl}(5.64 \%), \mathrm{Ba}(3.53 \%)$, C $(29.88 \%)$, O $(42.19 \%)$. Although the composition of this amorphous phase presumably depends on the composition of the initial solution, it is expected that its subsequent transformation results in the formation of a limited number of crystalline phases with an essentially constant stoichiometry. Between 3 and $24 \mathrm{~h}$ of aging, the amorphous precipitate formed by mixing solutions $\mathrm{A}$ and $\mathrm{B}$ partially crystallizes and witherite, northupite and norsethite coexist in the slurry. After $24 \mathrm{~h}$ of aging, the intensities of the diffraction peaks of witherite and northupite rapidly decrease whereas those of the peaks of norsethite increase progressively (see Fig. 1a). At any time, all of the peaks of norsethite, including the "dolomite-type" superstructure reflections, can be identified (see Fig. 1b).

Two-dimensional stacking of diffractograms collected at fixed time intervals allowed us to monitor changes in the mineralogy of the precipitates during the whole reaction (see Fig. 2). As can be clearly seen in this figure, the initial amorphous precipitate partially transforms into witherite, northupite and norsethite within the first $3 \mathrm{~h}$ of aging. After $24 \mathrm{~h}$ of reaction, the only remaining crystalline phases are norsethite and some traces of northupite (which can be explained by the excess of magnesium, sodium and chlorine in the initial solution). During the reaction, $\mathrm{pH}$ slightly decreases from 11.14, measured at the time of solution mixing, to 10.53 , recorded $24 \mathrm{~h}$ later. No significant fluctuations in the $\mathrm{pH}$ were recorded in this reaction time (see pH plot in Fig. 2).

The phase evolution shown in Fig. 2 indicates that the formation of norsethite from a highly supersaturated solution with respect to this mineral involves several reaction steps. The first of such steps is the precipitation of an amorphous gel-like phase despite the fact that the solution is supersaturated with respect to several carbonate crystalline phases, including norsethite. As it is known from previous experiments, at very high supersaturations the formation of amorphous carbonates is more kinetically favorable than the precipitation of their crystalline equivalents (e.g., Addadi et al., 2003; Radha et al., 2012). Such amorphous phases are metastable and eventually transform into crystalline carbonates with time (e.g., Koga et al., 1998; Radha et al., 2010). In the present case, this transformation does not result in one crystalline phase but into a mixture of witherite, northupite and norsethite. This mineral assemblage is also metastable and it evolves towards equilibrium. While these three phases initially crystallize at the expense of the amorphous precipitate, witherite and northupite begin to disappear after a few hours of aging in favor of norsethite. This second step towards the formation of norsethite also occurs through a dissolution-crystallization mechanism, whereby more soluble particles of northupite and witherite dissolve, while spherulitic aggregates of less soluble norsethite crystals grow (see Fig. 3). This solventmediated ripening process is consistent with the observed increase in particle size during the whole reaction period studied (from less than $1 \mu \mathrm{m}$ at $2 \mathrm{~h}$ of reaction to about $10 \mu \mathrm{m}$ after 14 days of slurry aging).

On the basis of the identified phases and their general evolution, the overall two-step reaction for the formation of norsethite can be proposed:

Amorphous phase $(\mathrm{Mg}, \mathrm{Ba}, \mathrm{Cl}, \mathrm{Na}, \mathrm{C}, \mathrm{O})$

$$
\begin{aligned}
& \quad \rightarrow \mathrm{Na}_{3} \mathrm{Mg}\left(\mathrm{CO}_{3}\right)_{2} \mathrm{Cl}_{\text {(northupite) }}+\mathrm{BaCO}_{3 \text { (witherite) }} \\
& \mathrm{Na}_{3} \mathrm{Mg}\left(\mathrm{CO}_{3}\right)_{2} \mathrm{Cl}_{\text {(northupite) }}+\mathrm{BaCO}_{3 \text { (witherite) }} \\
& \quad \rightarrow \mathrm{BaMg}\left(\mathrm{CO}_{3}\right)_{2 \text { (norsethite) }}+3 \mathrm{Na}^{+}+\mathrm{Cl}^{-}+\mathrm{CO}_{3}^{2-}
\end{aligned}
$$

The progress of the above two-step reaction leads to changes in the relative amounts of the phases, which can be estimated from the changes in the intensities of peaks in the diffractograms collected at different time intervals. Fig. 4 shows the evolution of the weight $\%$ of the amorphous phase, northupite, witherite and norsethite. Percentages were calculated from the diffractograms using the reference intensity rate (RIR) method (Hubbard and Snyder, 1988). Although this method only provides semiquantitative data, it reveals interesting information about the process leading to the generation of norsethite from an amorphous precipitate. As expected, at the beginning of the reaction the weight of the amorphous phase is almost $100 \%$. While this percentage rapidly decreases during the first $3 \mathrm{~h}$ of reaction, the amounts of northupite, witherite and norsethite increase. Furthermore, between 3 and $24 \mathrm{~h}$ of aging, the weight percentages of all the phases, including the amorphous phase, oscillate with decreasing amplitudes. 

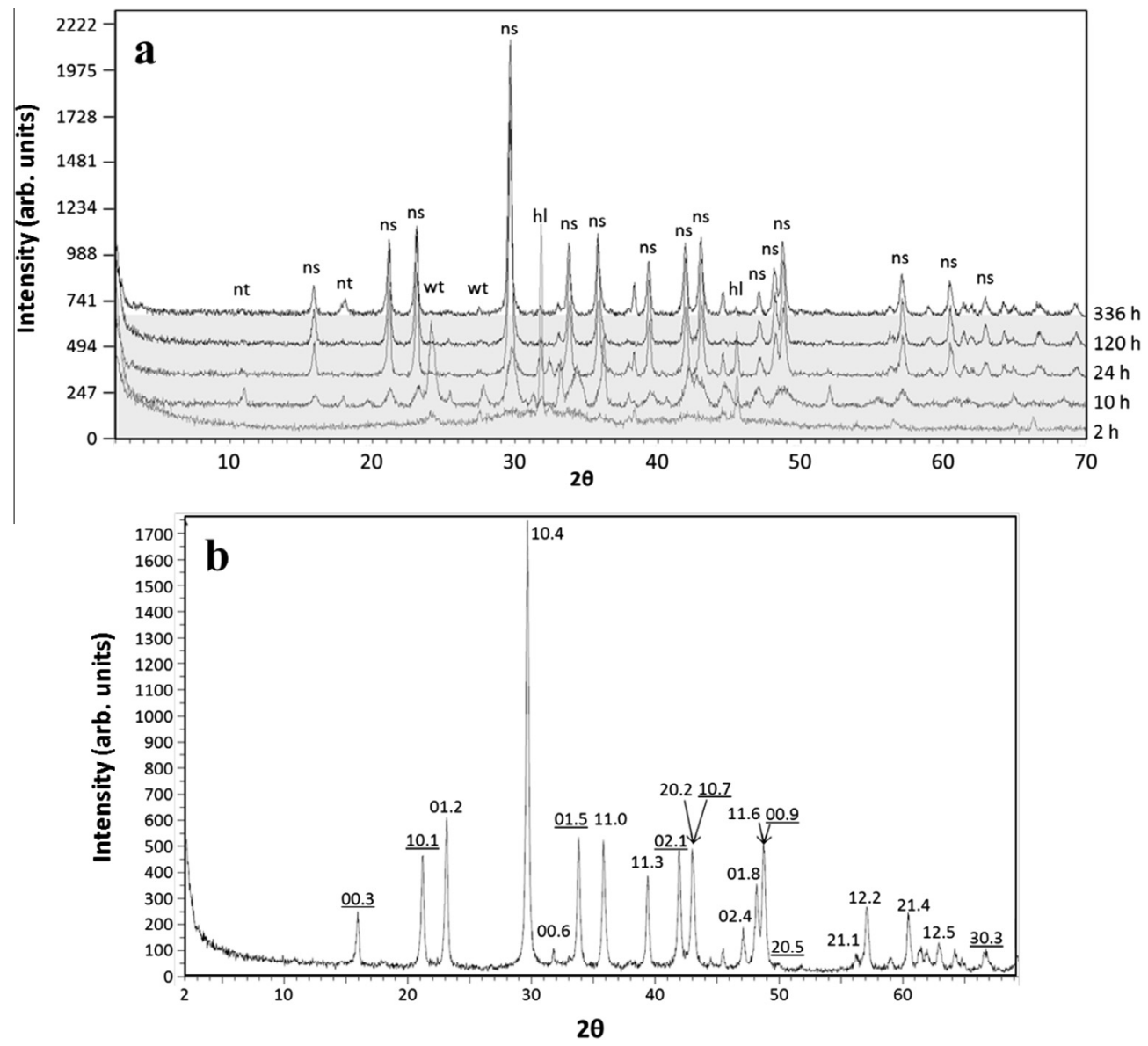

Fig. 1. (a) Diffractograms taken after 2, 10, 24, 120 and $336 \mathrm{~h}$ of reaction in which peaks of northupite (np), witherite (wt), norsethite (ns) and halite (hl) have been identified. Phase identification was conducted by automatic comparison of the diffractogram with the following PDF files: 74-1843 (northupite), 71-2394 (witherite) and 75-1463 (norsethite). (b) Indexed diffractogram of norsethite collected after 13 days of reaction. Superstructure reflections are underlined.

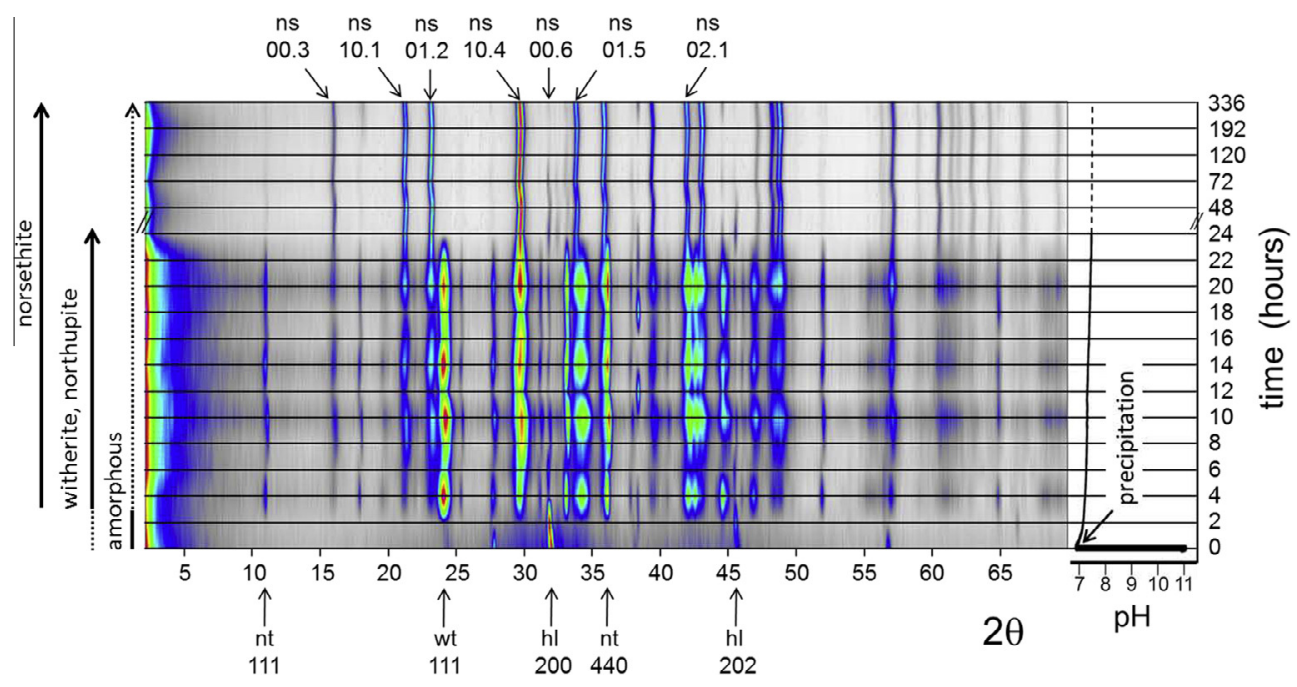

Fig. 2. Two-dimensional stacking of diffractograms taken during the first 14 days of aging of the slurry formed after mixing solution $\mathrm{A}$ $\left(0.06 \mathrm{M}\right.$ of $\mathrm{BaCl}_{2} ; 0.1 \mathrm{M}$ of $\left.\mathrm{MgCl}_{2}\right)$ and solution $\mathrm{B}\left(0.5 \mathrm{M}\right.$ of $\left.\mathrm{Na}_{2} \mathrm{CO}_{3}\right)$ at room temperature. The sequence of solid phases are indicated by arrows. Solid lines correspond to phases for which all of the diffraction peaks have been identified; dotted lines denote identification based on a few and weak diffraction peaks. The evolution of the main diffraction peaks are also indicated. Abbreviations: ns (norsethite), np (northupite), wt (witherite) and $\mathrm{hl}$ (halite). The $\mathrm{pH}$ plot shows the evolution of this parameter during the whole aging process. 


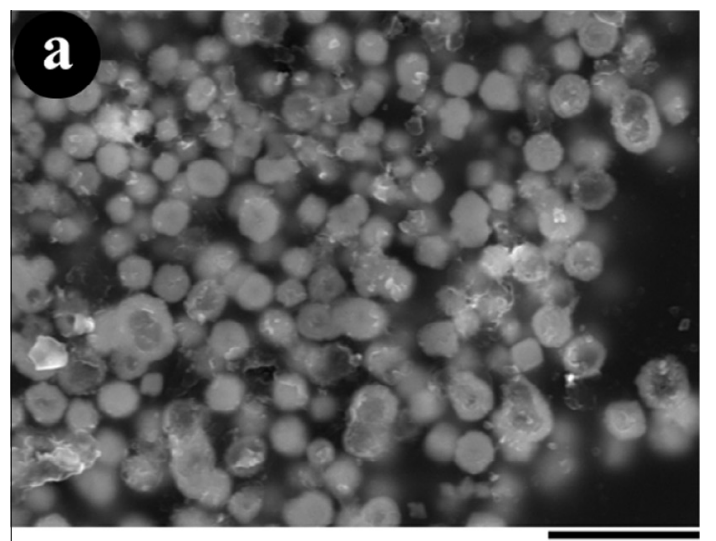

$5 \mu \mathrm{m}$

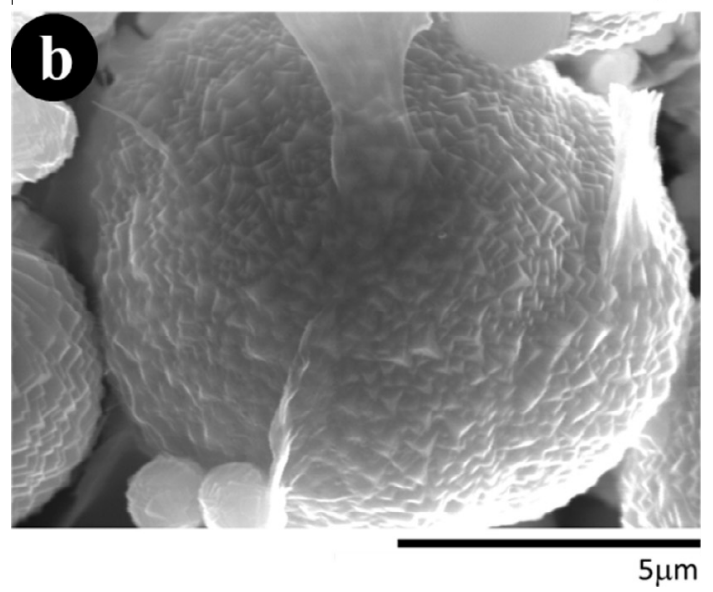

Fig. 3. Scanning electron micrographs showing norsethite spherulites developed after (a) $24 \mathrm{~h}$ and (b) 6 days (=144 h) of aging. As can be seen in (a), spherulites consist of numerous randomly oriented crystals which show rhombohedral $\{10.4\}$ faces.

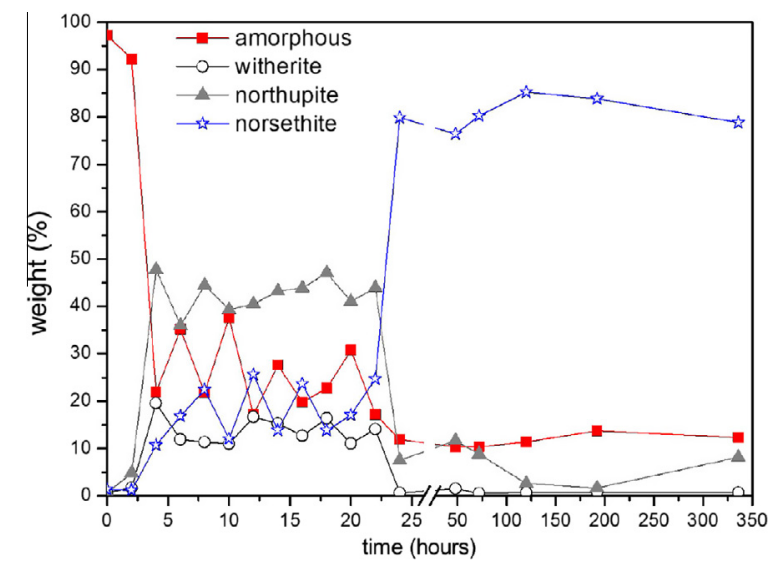

Fig. 4. Evolution of the weight $\%$ of the solid phases during 14 days of aging of a slurry formed after mixing solution $\mathrm{A}(0.06 \mathrm{M}$ of $\mathrm{BaCl}_{2} ; 0.1 \mathrm{M}$ of $\left.\mathrm{MgCl}_{2}\right)$ and solution $\mathrm{B}\left(0.5 \mathrm{M}\right.$ of $\left.\mathrm{Na}_{2} \mathrm{CO}_{3}\right)$ at room temperature.

These oscillations are not synchronic and maxima and minima are shifted. After $24 \mathrm{~h}$ of aging, large oscillations stop and a rapid increase in the amount of norsethite at the expense of the other phases is observed. This behavior further supports a mechanism of norsethite formation by the coupling of dissolution-crystallization reactions. In our experiments, witherite and northupite are the only crystalline phases identified as precursors of norsethite. Interestingly, other potential precursors, such as hydrous magnesium carbonates (e.g., hydromagnesite $\left(\mathrm{Mg}_{5}\left(\mathrm{CO}_{3}\right)_{4}(\mathrm{OH})_{2} \cdot 4 \mathrm{H}_{2} \mathrm{O}\right)$ and nesqueonite $\left(\mathrm{MgCO}_{3} \cdot 3 \mathrm{H}_{2} \mathrm{O}\right)$ were not detected in the diffractograms. The absence of these phases can be related to the high concentration of chloride ions in the aqueous solution, which would favor the formation of northupite (Deelman, 2011).

Energy Dispersive X-ray (EDX) analyses showed that norsethite crystals formed by the two-step reaction described by Eqs. (1a) and (1b) are highly stoichiometric after $24 \mathrm{~h}$ of aging. From these analyses, the following norsethite average formula was calculated: $\mathrm{Ba}_{1.02} \mathrm{Mg}_{0.98}\left(\mathrm{CO}_{3}\right)_{2}$. EDX analyses also suggest that norsethite rapidly approaches the ideal $\mathrm{Ba}: \mathrm{Mg}=1$ ratio in the first hours of the reaction. The $\mathrm{Ba} / \mathrm{Mg}$ ratio close to one at the early stages of norsethite formation indicates that both cations incorporate into the norsethite structure at comparable rates, which casts doubt on the frequently invoked dehydration barrier of $\mathrm{Mg}^{2+}$ cation as being the main inhibiting factor of dolomite crystallization (Lippmann, 1973). Instead, the relatively ease of formation of norsethite supports the idea that differences in cationic radii play an essential role in the crystallization kinetics of dolomite-like structures (Xu et al., 2013). In norsethite structure, the large difference in $\mathrm{Ba}^{2+}$ and $\mathrm{Mg}^{2+}$ ionic radii correlates with an articulation of the $\mathrm{CO}_{3}$ groups, which results in larger coordination polyhedra compared to those found in the dolomite structure (Lippmann, 1973). These slight structural differences are also found in the double carbonate, $\mathrm{PbMg}\left(\mathrm{CO}_{3}\right)_{2}$, which can also be crystallized at room temperature (Lippmann, 1966; Morrow and Ricketts, 1986). This seems to indicate that structural constraints related to differences in cationic sizes might be determining for the crystallization behavior of minerals with dolomite-like structure.

The progressive formation of norsethite from an assemblage of witherite and northupite by way of a continuous dissolution-crystallization process is accompanied by changes in crystallinity and in cation ordering. Whereas the formation of norsethite can be detected by the 10.4 and 01.2 reflections in the X-ray diffractograms, the $\mathrm{Ba}-$ $\mathrm{Mg}$ ordering in the norsethite structure is evidenced by the $00.3,10.1,01.5,02.1,20.5$ and 30.3 superstructure reflections. All of these reflections appear from the time of the first detection of norsethite onward (Figs. 1 and 2). The widths of such peaks are not constant but decreases with time, indicating an increase in the coherence of the diffracted X-rays, which can be related to the growth process of norsethite. Fig. 5 shows the evolution of the full width half maximum (FWHM) of the norsethite 00.3, 10.1 and 10.4 peaks during the 14 days of reaction. The decrease observed in the FWHM of structure and superstructure reflections can be interpreted as representing an increase in the size, crystallinity and cation ordering in norsethite crystals with time. 


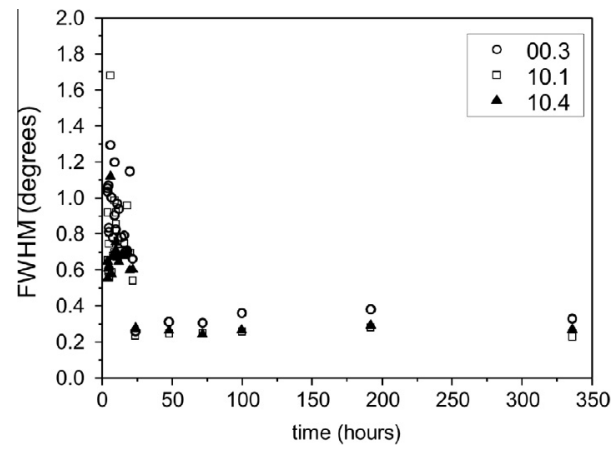

Fig. 5. Full width half maximum for the norsethite 10.4 reflection and the 00.3 and 10.1 superstructure reflections plotted versus time.
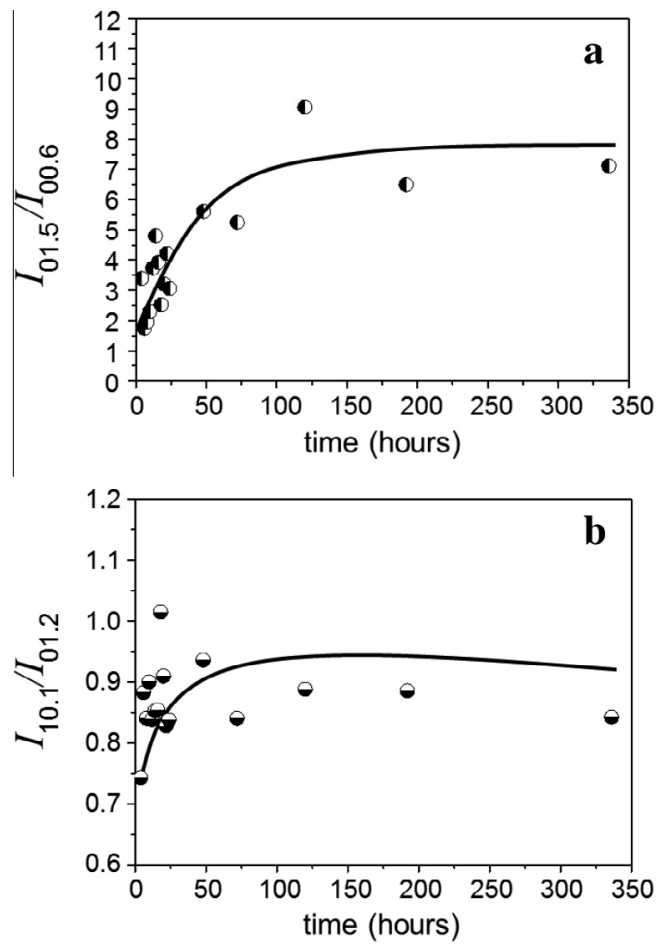

Fig. 6. Evolution during 14 days $\left(=336 \mathrm{~h}\right.$ ) of (a) the $I_{01.5} / I_{00.6}$ intensity ratio and (b) the $I_{10.1} / I_{01.2}$ intensity ratio of norsethite peaks. Solid lines were drawn to guide the eye.

According to Schultz-Güttler (1986), the degree of cation ordering in the dolomite structure can be estimated from the ratio of the intensities of selected superstructure and structure reflections, i.e., by quantifying the relative intensity of reflections whose structure factor contributions are mainly due to the difference in scattering factors of $\mathrm{Ca}$ and $\mathrm{Mg}$ atoms. More specifically, Schultz-Güttler (1986) used the $I_{01.5} / I_{00.6}$ ratio to characterize the $\mathrm{Ca}-\mathrm{Mg}$ ordering in a number of natural dolomites. In the present investigation we have used, in addition to the $I_{01.5} / I_{00.6}$ ratio, the $I_{10.1} / I_{01.2}$ ratio to evaluate the degree of $\mathrm{Ba}-\mathrm{Mg}$ ordering in the norsethite lattice. Both intensity ratios seem to account for the general evolution of norsethite superstructure reflections. However, some norsethite peaks can occasionally overlap with peaks of witherite and northupite (e.g., the norsethite 10.1 peak is close to the northupite 331 reflection, and the norsethite 01.5 peak can overlap with the witherite 200 reflection). This could lead to overestimations of intensity ratios calculated from those diffractograms collected during the first day of aging. Furthermore, certain intensity changes in structure reflections might be partially influenced by the ordering process and/or by changes in crystallinity (e.g., the 01.2 reflection). Although these possible effects on the intensities seem to be minor, they introduce some uncertainties in the calculation of the intensity ratios. Therefore, $I_{01.5} / I_{00.6}$ and $I_{10.1} / I_{01.2}$ ratios must be considered only as approximate indicators of the $\mathrm{Ba}-\mathrm{Mg}$ ordering in norsethite.

Fig. 6 shows the evolution of the $I_{01.5} / I_{00.6}$ and $I_{10.1} / I_{01.2}$ ratios during the aging of the slurry. As can be seen, an increase in the relative intensities of superstructure reflections occurred in the first $48 \mathrm{~h}$ of reaction, indicating that the $\mathrm{Ba}-\mathrm{Mg}$ ordering in the norsethite structure mainly takes place during the first few hours of aging. Although a mechanism of ordering cannot be deduced from our experimental data, it is plausible that a progressive increase in ordering of the norsethite structure occurs by a solventmediated diffusion of $\mathrm{Ba}$ and $\mathrm{Mg}$ between cationic monolayers during the aging process.

\section{CONCLUSIONS}

The results presented in this paper show that the formation of norsethite at room temperature from a solution highly supersaturated with respect to this mineral occurs by a sequence of dissolution-crystallization reactions from an initially precipitated amorphous phase. The transformation of such an amorphous precursor into an assemblage of witherite, northupite and norsethite results in micron-sized norsethite crystal aggregates after about $24 \mathrm{~h}$ of aging. $\mathrm{X}$-ray diffraction data indicate that the construction of the dolomite-like structure of norsethite with complete $\mathrm{Ba}-\mathrm{Mg}$ ordering requires a ripening process in which witherite and northupite seem to act as local reservoirs of $\mathrm{Ba}$ and $\mathrm{Mg}$, respectively. In particular, the presence of northupite in the slurry seems to play a role in the transfer of $\mathrm{Mg}^{2+}$ to the norsethite crystal surfaces during growth. This observation supports the hypothesis that alkali-bearing carbonate solutions are suitable natural media for the formation of minerals of the dolomite group (Lippmann, 1973).

The progress of the dissolution-crystallization reactions which lead to the formation of norsethite has been monitored by analyzing the evolution of diffractograms of precipitates collected at fixed time intervals. Apart from the dissolution of witherite and northupite in favor of norsethite, diffractograms provided evidence that both crystallinity and cation ordering increase during the first $48 \mathrm{~h}$ of slurry aging. Such crystallographic evolution towards the formation of fully-ordered norsethite has been quantified using the full width half maximum (FWHM) and the $I_{01.5} / I_{00.6}$ and $I_{10.1} / I_{01.2}$ ratios as proxies of crystallinity and $\mathrm{Ba}-\mathrm{Mg}$ cation ordering, respectively. Although these proxies must be taken with caution due to possible uncertainties in the 
determination of peak intensities, they may be useful to conduct further comparative investigations on the precipitation of other minerals with dolomite-like structures.

The findings presented in this paper provide new insight into the chemical pathways and ordering mechanisms that lead to the formation of double carbonates such as dolomite under conditions of room temperature and atmospheric pressure.

\section{ACKNOWLEDGMENTS}

This work was supported by the Spanish Government (Project MAT2012-38810). SEM images and EDX analyses were obtained at the ICTS Centro Nacional de Microscopia Electrónica, (UCM) Madrid. Carlos Pimentel wishes to thank the Spanish Government for a FPU Fellowship. This paper benefited from insightful comments by J.C. Deelman, Alejandro FernándezMartínez and two anonymous reviewers.

\section{REFERENCES}

Addadi L., Raz S. and Weiner S. (2003) Taking advantage of disorder: amorphous calcium carbonate and its roles in biomineralization. Adv. Mater. 15, 959-970

Böttcher M. E. (2000) Stable isotope fractionation during experimental formation of norsethite $\left(\mathrm{BaMg}\left[\mathrm{CO}_{3}\right]_{2}\right)$ : a mineral analogue of dolomite. Aquat. Geochem. 6, 201-212.

Deelman J. C. (2011) Low-Temperature Formation of Dolomite and Magnesite, Version 2.3. p. 512.

Hood W. C., Steidl P. F. and Tschopp D. G. (1974) Precipitation of norsethite at room temperature. Am. Mineral. 59, 471-474.

Hubbard C. R. and Snyder R. L. (1988) RIR-measurement and use in quantitative XRD. Powder Diffr. 3(2), 74-77.

Koga N., Nakagoe Y. and Tanaka H. (1998) Crystallization of amorphous calcium carbonate. Thermochim. Acta 318, 239244.

Königsberger E., Tran-Ho Lan-Ch and Gamsjäger H. (1998) Solidsolute phase equilibria in aqueous solutions X. Solubility constant and stability of norsethite. Monatsh. Chem. 129, $1061-1066$

Liebermann O. (1967) Synthesis of dolomite. Nature 213, 241-245.

Lippmann F. (1966) $\mathrm{PbMg}\left(\mathrm{CO}_{3}\right)_{2}$, ein neues rhomboedrisches Doppelcarbonat. Jg. Heft. 24, 701.
Lippmann F. (1967) Die Synthese des Norsethits, $\mathrm{BaMg}\left(\mathrm{CO}_{3}\right)_{2}$, bei ca. 20 und 1at. ein Modell zur Dolomitisierung. Neues Jahrb. Mineral. Monats. 12, 23-29.

Lippmann F. (1973) Sedimentary Carbonate Minerals. SpringerVerlag, p. 228.

Morrow D. W. and Ricketts B. D. (1986) Chemical controls on the precipitation of mineral analogues of dolomite: the sulfate enigma. Geology 14, 408-410.

Parkhurst D. L. and Appelo C. A. J. (1999) User's guide to PHREEQC (version 2) - a computer program for speciation, reaction-path, 1Dtransport, and inverse geochemical calculations. U.S. Geological Survey, Water-Resources Investigations Report 99-4259.

Radha A. V., Forbes T. Z., Killian C. E., Gilbert P. U. P. A. and Navrotsky A. (2010) Transformation and crystallization energetics of synthetic and biogenic amorphous calcium carbonate. Proc. Natl. Acad. Sci. USA 107, 16438-16443.

Radha A. V., Fernández-Martínez A., Yandi Hu Y., Jun Y.-S., Waychunas G. A. and Navrotsky A. (2012) Energetic and structural studies of amorphous $\mathrm{Ca}_{1-x} \mathrm{Mg}_{x} \mathrm{CO}_{3} \cdot \mathrm{nH}_{2} \mathrm{O}$ $(0 \leqslant x \leqslant 1)$. Geochim. Cosmochim. Acta 90, 83-95.

Roberts J. A., Kenward P. A., Fowle D. A., Goldstein R. H., González L. A. and Moore D. S. (2013) Surface chemistry allows for abiotic precipitation of dolomite at low temperature. Proc. Natl. Acad. Sci. USA 110, 14540-14545.

Schultz-Güttler R. (1986) The influence of disordered, non-equilibrium dolomites on the $\mathrm{Mg}$-solubility in calcite in the system $\mathrm{CaCO}_{3}-\mathrm{MgCO}_{3}$. Contrib. Miner. Petrol. 93, 395-398.

Vančina V., Plavšić M., Bilinski H. and Branica M. (1986) Preparation and solubility of northupite from brine and its adsorption properties for $\mathrm{Cu}(2)$ and $\mathrm{Cd}(2)$ in seawater. Geochim. Cosmochim. Acta 50, 1329-1336.

Vasconcelos C., McKenzie J. A., Bernasconi S., Grujic D. and Tien A. J. (1995) Microbial mediation as a possible mechanism for natural dolomite formation at low temperature. Nature 377, 220-222.

Warren J. (2000) Dolomite: occurrence, evolution and economically important associations. Earth Sci. Rev. 52, 1-81.

Xu J., Yan Ch., Zhang F., Konishi H., Xu H. and Teng H. (2013) Testing the cation-hydration effect on the crystallization of $\mathrm{Ca}-$ $\mathrm{Mg}-\mathrm{CO}_{3}$ systems. Proc. Natl. Acad. Sci. USA 110, 17750 17755 . 